\title{
Erythromycin Estolate
}

National Cancer Institute

\section{Source}

National Cancer Institute. Enythromycin Estolate. NCI Thesaurus. Code C47986.

The lauryl sulfate ester of propionyl erythromycin, a broad-spectrum, topical macrolide antibiotic with antibacterial activity. Erythromycin estolate diffuses through the bacterial cell membrane and reversibly binds to the $50 \mathrm{~S}$ subunit of the bacterial ribosome. This prevents bacterial protein synthesis. Erythromycin estolate may be bacteriostatic or bactericidal in action, depending on the concentration of the drug at the site of infection and the susceptibility of the organism involved. 